\title{
PENGARUH STRUKTUR MODAL DAN NON PERFORMING LOAN (NPL) TERHADAP NILAI PERUSAHAAN PADA PT BANK RAKYAT INDONESIA (PERSERO), TBK YANG TERDAFTAR DI BURSA EFEK INDONESIA
}

\author{
Oleh: \\ Ananta Irdavani \\ S1 Akuntansi \\ Pinondang Nainggolan, Jubi, Elly Susanti
}

Abstraksi

Tujuan dari penelitian ini adalah untuk mengetahui gambaran struktur modal, Non Performing Loan (NPL) dan nilai perusahaan serta pengaruh struktur modal dan Non Performing Loan (NPL) terhadap nilai perusahaan pada PT Bank Rakyat Indonesia (Persero), Tbk yang terdaftar di Bursa Efek Indonesia baik secara simultan maupun parsial. Metode analisis yang digunakan dalam penelitian ini adalah metode analisis deskriptif kualitatif dan analisis deskriptif kuantitatif. Objek penelitian ini adalah PT Bank Rakyat Indonesia (Persero), Tbk yang terdaftar di Bursa Efek Indonesia tahun 2007-2014. Teknik analisis kuantitatif yang digunakan adalah regresi linear berganda, koefisien korelasi dan determinasi, uji $\mathrm{F}$ dan uji t. Analisis data dilakukan dengan menggunakan bantuan software statistic SPSS 19.

Hasil analisa dari regresi linier berganda yaitu: $\mathrm{Y}=2,660-0,011 \mathrm{X}_{1}+0,269 \mathrm{X}_{2}+$. Hal ini menunjukkan bahwa struktur modal yang diproksikan dengan Capital Adequacy Ratio (CAR) memiliki pengaruh negatif dan Non Performing Loan (NPL) berpengaruh positif terhadap nilai perusahaan yang diproksikan dengan Market to Book Ratio (MBR). Hasil kolerasi yaitu $\mathrm{r}=0,554$ artinya hubungan antara CAR dan NPL dengan MBR cukup kuat. Dari koefisien determinasi MBR dapat dijelaskan oleh CAR dan NPL sebesar 30,7\% dan sisanya sebesar $69,3 \%$ dipengaruhi oleh faktor lain di luar variabel dalam penelitian ini. Hipotesis penelitian $\mathrm{H}_{0}$ diterima dengan tingkat signifikansi 0,093 lebih besar dari 5\% atau 0,05, artinya Capital Adequacy Ratio (CAR) dan Non Performing Loan (NPL) secara simultan berpengaruh tidak signifikan terhadap Market to Book Ratio (MBR) PT Bank Rakyat Indonesia (Persero), Tbk yang terdaftar di Bursa Efek Indonesia.

Kata Kunci : Struktur Modal, Non Performing Loan (NPL), dan Nilai Perusahaan

\section{Abstraction}

The purpose of this research are to identify the description of capital structure, Non Performing Loan (NPL) and firm value and analyze the effect of capital structure, Non Performing Loan (NPL) to the firm value on PT Bank Rakyat Indonesia (Persero), Tbk listed on Indonesia Stock Exchange either simultanly or partially. Methods of analysis used in this study are descriptive analysis of qualitative methods and quantitative descriptive analysis. The object of this research is PT Bank Rakyat Indonesia (Persero), Tbk listed on Indonesia Stock Exchange in 2007-2014. Analytical quantitative techniques used are multiple linear regression, correlation and coefficient of determination, F-test and t-test. Data analysis was done using SPSS statistic software assistance 19.

Result of analysis multiple linear regression that is $Y=2,660-0,011 X_{1}+0,269 X_{2}+$. This shows that capital structure is proxied by Capital Adequacy Ratio (CAR) have a negative effect and Non Performing Loan $(N P L)$ have a positive effect on the firm value is proxied by Market to Book Ratio (MBR). The test results of correlation is $r=0,554$ means that the relationship between the CAR and NPL with the MBR is strong enough. From coefficient determination MBR can be explained by the CAR and NPL mounted to $30,7 \%$, and the rest $69,3 \%$, is explained by other factors that are not discussed in this study. The research hypothesis $H_{0}$ is accepted with the significance level 0,093 bigger than 5\% or 0,05, means that the Capital Adequacy Ratio (CAR) and Non Performing Loan (NPL) simultanly have not significant effect to the Market to Book Ratio (MBR) on PT Bank Rakyat Indonesia (Persero), Tbk listed on Indonesia Stock Exchange.

Keywords: Capital Structure, Non Performing Loan (NPL) and Firm Value 


\section{A. PENDAhUluan}

\section{Latar Belakang Masalah}

Perbankan merupakan salah satu sektor yang berperan penting dalam perekonomian di Indonesia. Bahkan dalam kehidupan masyarakat modern sehari-hari sebagian besar melibatkan jasa dari sektor perbankan. Persaingan bisnis yang semakin ketat menuntut bank untuk meningkatkan kinerjanya agar dapat menarik dana dari para investor. Dalam menginvestasikan dananya, investor memerlukan informasi mengenai kinerja perusahaan.

Untuk menilai perusahaan, maka sumber data yang utama dipergunakan oleh berbagai pihak yaitu laporan keuangan perusahaan. Menurut Horne dan John (2012:3), ada beberapa faktor yang mempengaruhi nilai perusahaan yaitu keputusan investasi, keputusan pendanaan dan keputusan manajemen aset. Untuk meningkatkan nilai perusahaan, bank harus memperhatikan ketiga faktor tersebut. Nilai perusahaan dapat diukur dengan Market to Book Ratio (MBR). Market to Book Ratio (MBR) yang tinggi akan membuat pasar percaya atas kemakmuran perusahaan kedepannya.

Sebagai perusahaan yang kegiatannya menghimpun dana, bank harus memperhatikan perencanaan yang matang dalam keputusan pendanaan. Menurut Ali (2006:427), struktur permodalan suatu bank adalah cara yang ditempuh bank tersebut dalam membiayai aset dan kegiatan bisnisnya. Struktur permodalan bank bercirikan adanya tingkat leverage yang jauh lebih tinggi. Hal itu tampak pada angka besaran Capital Adequacy Ratio (CAR) yang diwajibkan tidak boleh lebih rendah lagi dari sedikitnya $8 \%$. Karena tingginya financial leverage yang terdapat dalam struktur permodalan bank, terselip risiko bila karena suatu hal bank mengalami kegagalan.

Salah satu risiko yang menyebabkan bank mengalami kegagalan adalah tingginya jumlah kredit bermasalah. Kredit bermasalah atau biasa disebut Non Performing Loan (NPL) merupakan kredit yang menunggak melebihi 90 hari yang terdiri atas kredit kurang lancar, kredit diragukan dan kredit macet. Non Performing Loan (NPL) adalah salah satu indikator untuk menilai kinerja fungsi bank. Jika pengelolaan kredit dilakukan secara baik dan menggunakan prinsip kehati-hatian maka akan menghasilkan laba bagi perusahaan sehingga akan meningkatkan nilai perusahaan.

\section{Rumusan Masalah}

a. Bagaimana gambaran struktur modal, Non Performing Loan (NPL) dan nilai perusahaan pada PT Bank Rakyat Indonesia, Tbk yang terdaftar di Bursa Efek Indonesia?

b. Bagaimana pengaruh struktur modal dan Non Performing Loan (NPL) terhadap nilai perusahaan pada PT Bank Rakyat Indonesia, Tbk yang terdaftar di Bursa Efek Indonesia baik secara parsial maupun simultan?

\section{Tujuan Penelitian}

a. Untuk mengetahui gambaran struktur modal dan Non Performing Loan (NPL) terhadap nilai perusahaan pada PT Bank Rakyat Indonesia, Tbk yang terdaftar di Bursa Efek Indonesia.

b. Untuk mengetahui dan menganalisis pengaruh struktur modal dan Non Performing Loan (NPL) terhadap nilai perusahaan pada PT Bank Rakyat Indonesia, Tbk yang terdaftar di Bursa Efek Indonesia baik secara parsial maupun simultan.

\section{Metode Penelitian}

Dalam penelitian ini, penulis mengambil objek penelitian pada PT Bank Rakyat Indonesia (Persero), Tbk yang terdaftar di Bursa Efek Indonesia yang beralamat di Jl. Jend. Sudirman No. 44-46 Tromol Jakarta 10210. Objek penelitian diperoleh penulis dengan mengakses situs www.idx.co.id

Adapun desain penelitian yang digunakan dalam penulisan penelitian ini adalah penelitian kepustakaan (library research). Teknik pengumpulan data yang dilakukan penulis dalam penelitian ini adalah dokumentasi. Adapun jenis data yang digunakan dalam penelitian ini adalah jenis data kualitatif dan data kuantitatif. Hasil data yang diperoleh akan dianalisis secara deskriptif baik bersifat kualitatif dan kuantitatif.

\section{B. LANDASAN TEORI}

\section{Laporan Keuangan Bank}

Menurut Ismail (2010:15), laporan keuangan bank merupakan bentuk pertanggungjawaban manajemen terhadap pihak-pihak yang berkepentingan dengan kinerja yang dicapai selama periode tertentu. Menurut Ismail (2010:15) komponen laporan keuangan bank yang lengkap terdiri dari:

a. Neraca, merupakan laporan yang menunjukkan posisi keuangan meliputi harta, kewajiban dan ekuitas bank pada tanggal tertentu, yaitu pada tanggal pelaporan.

b. Laporan Komitmen dan Kontingensi, merupakan laporan yang terpisah dari neraca dan laporan laba/rugi yang mana pada saat yang akan datang akan dapat mempengaruhi neraca dan/atau laporan laba/rugi bank.

c. Laporan Laba/Rugi, merupakan laporan yang menggambarkan pendapatan dan beban bank pada periode pelaporan. 
d. Laporan Perubahan Ekuitas, adalah laporan yang menunjukkan perubahan ekuitas perusahaan yang menggambarkan peningkatan atau penurunan aktiva bersih atau kekayaan bank selama periode pelaporan.

e. Laporan Arus Kas, merupakan informasi yang digunakan untuk mengetahui perubahan-perubahan aktivitas keuangan yang terkait dengan transaksi tunai.

f. Catatan Atas Laporan Keuangan, merupakan informasi terkait dengan semua aktivitas keuangan yang tidak dapat dipisahkan dari laporan keuangan, termasuk di dalamnya laporan komitmen dan kontingensi.

\section{Analisis Laporan Keuangan}

Menurut Wild, et. al (2005:3), analisis laporan keuangan adalah aplikasi dari alat dan teknik analisis untuk laporan keuangan bertujuan umum dan data-data yang berkaitan untuk menghasilkan estimasi dan kesimpulan yang bermanfaat dalam analisis bisnis. Menurut Munawir (2010:36), teknik analisis laporan keuangan terdiri dari :

a. Analisis Perbandingan Laporan Keuangan

Metode dan teknik analisis dengan cara memperbandingkan laporan keuangan untuk dua periode atau lebih.

b. Analisis Trend atau tendensi posisi dan kemajuan keuangan perusahaan yang dinyatakan dalam presentase (trend percentage analysis)

c. Analisis Laporan Persentase Per Komponen (Common Size Statement)

d. Analisis Sumber dan Penggunaan Modal Kerja

e. Analisis Sumber dan Penggunan Kas (Cash Flow Statement Analysis)

f. Analisis Rasio adalah suatu analisis untuk mengetahui hubungan dari akun-akun tertentu dalam neraca atau laporan laba rugi secara individu atau kombinasi dari kedua laporan tersebut.

g. Analisis Perubahan Laba Kotor (Gross Profit Analysis)

h. Analisis Break Even Point adalah suatu analisis untuk menentukan tingkat penjualan yang harus dicapai oleh suatu perusahaan agar perusahaan tersebut tidak mengalami kerugian, tetapi juga belum memperoleh keuntungan.

\section{Rasio Keuangan Bank}

Menurut Kasmir (2010:93), rasio keuangan merupakan kegiatan membandingkan angka-angka yang ada dalam laporan keuangan dengan cara membagi satu angka dengan angka lainnya. Kemudian angka yang diperbandingkan dapat berupa angka-angka dalam satu periode maupun beberapa periode.

Menurut Dendawijaya (2005:114), jenis-jenis rasio keuangan bank yaitu:

a. Rasio Likuiditas adalah analisis yang dilakukan terhadap kemampuan bank dalam memenuhi kewajibankewajiban jangka pendeknya atau kewajiban yang sudah jatuh tempo.

b. Rasio Rentabilitas adalah alat untuk menganalisis atau mengukur tingkat efisien usaha dan profitabilitas yang dicapai oleh bank yang bersangkutan. Selain itu, rasio-rasio ini dapat pula digunakan untuk mengukur tingkat kesehatan bank.

c. Rasio Solvabilitas adalah analisis yang digunakan untuk mengukur kemampuan bank dalam memenuhi kewajiban jangka panjang atau kemampuan bank untuk memenuhi kewajiban-kewajiban jika terjadi likuidasi bank.

\section{Struktur Modal}

Menurut Ali (2006:427), struktur permodalan suatu bank adalah cara yang ditempuh bank tersebut dalam membiayai aset dan kegiatan bisnisnya. Cara pembiyaan itu biasanya merupakan kombinasi dari sumber-sumber pembiayaan berupa: saham, penerbitan surat utang, obligasi, dan beragam jenis pinjaman lainnya.

Menurut Ali (2006:428), risiko yang terbentuk sebagai akibat dari kegiatan operasional bank harus sejalan pula dengan upaya bank untuk mempertahankan besaran modal bank, sesuai dengan tingkat yang disepakati oleh regulator. Oleh karena itu, bank diwajibkan menjaga kecukupan modalnya dalam mengatasi risiko yang dihadapinya. Kecukupan modal itu dikenal dengan istilah "capital adequacy".

Menurut Dendawijaya (2005:121), Capital Adequacy Ratio (CAR) adalah rasio yang memperlihatkan seberapa jauh seluruh aktiva bank yang mengandung risiko (kredit, pernyertaan, surat berharga, tagihan pada bank lain) ikut dibiayai dari dana modal sendiri bank, di samping memperoleh dana-dana dari sumber di luar bank seperti dana masyarakat, pinjaman (utang) dan lain-lain. Selanjutnya menurut Darmawi (2011:97), Capital Adequacy Ratio (CAR) merupakan perbandingan antara modal dengan aktiva tertimbang menurut risiko.

$$
\text { CAR }=\frac{\text { Modal Bank }}{\text { Aktiva Tertimbang Menurut Risiko }} x 100 \%
$$

\section{Non Performing Loan (NPL)}

Menurut Hariyani (2010:52), rasio Non Performing Loan (NPL) atau rasio kredit bermasalah, rasio ini menunjukkan kemampuan manajemen bank dalam mengelola kredit bermasalah yang diberikan oleh bank. 
Menurut Taswan (2010:166), Rasio Non Performing Loan (NPL) yaitu perbandingan antara kredit bermasalah terhadap total kredit. Rasio ini mengindikasikan bahwa semakin tinggi rasio Non Performing Loan (NPL) menunjukkan semakin buruk kualitas kreditnya.

$$
\mathrm{NPL}=\frac{\text { Kredit Bermasalah }}{\text { Total Kredit }} \times 100 \%
$$

\section{Nilai Perusahaan}

Menurut Keown, et. al. (2004:470), nilai perusahaan merupakan nilai pasar atas surat berharga, hutang dan ekuitas pemegang saham yang beredar. Menurut Brigham dan Joel (2012:150), rasio nilai pasar terdiri atas:

a. Rasio Harga/Laba

Rasio harga/laba (pricelearnings-P/E) menunjukkan jumlah yang rela dibayarkan oleh investor untuk setiap laba yang dilaporkan.

b. Rasio Harga/Arus Kas

$$
\text { Rasio harga/laba }=\frac{\text { Harga per saham }}{\text { Laba per saham }}
$$

Rasio harga/arus kas (price/cash flow ratio) yaitu rasio harga per saham dibagi dengan arus kas per saham, menunjukkan jumlah yang akan dibayarkan investor untuk setiap arus kas.

c. Rasio Nilai Pasar/Nilai Buku

$$
\text { Rasio arus kas }=\frac{\text { Harga per saham }}{\text { arus kas per saham }}
$$

Rasio nilai pasar/nilai buku (Market/book-M/B) yaitu perbandingan antara harga pasar perlembar saham dengan nilai buku perlembar saham.

$$
\text { Rasio nilai pasar }=\frac{\text { Harga pasar per saham }}{\text { Nilai buku per saham }}
$$

\section{Pengaruh Struktur Modal dan Non Performing Loan (NPL) terhadap Nilai Perusahaan}

Darmawi (2011:18), yang menyatakan apabila ketentuan rasio kecukupan modal tidak terpenuhi, akan mengurangi ekspansi kredit dan mempengaruhi tingkat kesehatan bank yang akan mengurangi kepercayaan masyarakat. Menurut Taswan (2010:166), Rasio Non Performing Loan (NPL) yaitu perbandingan antara kredit bermasalah terhadap total kredit. Rasio ini mengindikasikan bahwa semakin tinggi rasio Non Performing Loan (NPL) menunjukkan semakin buruk kualitas kreditnya.

Selanjutnya menurut Taswan (2010:452), kualitas kredit yang semakin menurun (peningkatan kredit bermasalah) membawa pengaruh negatif terhadap bank selaku kreditor. Cadangan penyisihan kredit ini lawan rekening kerugian kredit. Kerugian kredit merupakan biaya yang berarti akan menurunkan laba. Penurunan laba bahkan kerugian bank akan berakibat menurunkan modal bank. Penurunan jumlah modal bank akan menurunkan Capital Adequacy Ratio (CAR). Penurunan Capital Adequacy Ratio (CAR) akan menurunkan kepercayaan masyarakat dan ini berarti mengancam keberlangsungan usaha perbankan.

\section{PEMBAHASAN}

\section{Analisa}

\section{a. Uji Asumsi Klasik}

Uji normalitas dengan pengujian One Sample Kolmogorov-Smirnov diperoleh nilai Asymp Sig. (2-tailed) sebesar 0,986 yang berarti nilai tersebut di atas nilai signifikan 0,986 > 0,05. Dengan demikian dapat dikatakan bahwa variabel residual berdistribusi normal. Untuk uji multikolineritas, menunjukkan bahwa variabel Capital Adequacy Ratio (CAR) dan Non Performing Loan (NPL) semuanya tidak terjadi multikolineritas karena nilai tolerance berada di atas 0,10 dan nilai VIF berada di bawah 10 .

Dari grafik scatterplot terlihat bahwa plot menyebar secara acak di atas maupun di bawah angka nol pada sumbu Regression Studentized Residual. Oleh karena itu, maka berdasarkan uji heteroskedastisitas menggunakan metode analisis grafik, pada model regresi yang terbentuk dinyatakan tidak terjadi gejala heteroskedastisitas. Nilai Durbin-Watson dalam penelitian ini adalah sebesar 1,777. Berdasarkan tabel DurbinWatson diketahui bahwa nilai dU untuk data sebanyak 16 dan variabel independen $(\mathrm{k})=2$ adalah 1,5386 sehingga 4-dU = 2,4614. Maka nilai uji $\mathrm{D}-\mathrm{W}$ sebesar 1,777 berada pada $\mathrm{dU}<\mathrm{dW}<4$-dU atau dapat dijelaskan bahwa $1,5386<1,777<2,4614$. Dengan demikian dapat dikatakan bahwa tidak terjadi autokorelasi.

\section{b. Deskriptif Kualitatif}

Analisis deskriptif dalam penelitian ini bertujuan untuk mendapatkan gambaran atau deskripsi mengenai Capital Adequacy Ratio (CAR), Non Performing Loan (NPL) dan Market to Book Ratio (MBR) pada PT Bank Rakyat Indonesia (Persero), Tbk yang terdaftar di Bursa Efek Indonesia periode 2007-2014 


\section{1) Capital Adequacy Ratio (CAR) pada PT Bank Rakyat Indonesia (Persero), Tbk yang terdaftar di Bursa Efek Indonesia Periode 2007-2014}

Dari hasil penelitian, diketahui nilai minimum CAR PT Bank Rakyat Indonesia (Persero), Tbk periode 2007-2014 adalah sebesar 13,18\% terdapat di tahun 2008 pada semester II sedangkan nilai maksimum CAR adalah sebesar $18,31 \%$ terdapat di tahun 2014 pada semester II. Nilai rata-rata CAR pada penelitian ini adalah sebesar $15,62 \%$.

Pada penelitian ini selama 8 semester, perusahaan memiliki nilai CAR di atas nilai rata-rata yang berarti nilai CAR yang semakin tinggi maka akan semakin besar jumlah modal untuk mengatasi resiko yang dihadapinya dan selama 8 semester juga nilai CAR berada di bawah nilai rata-rata, artinya rasio kecukupan modal yang lebih kecil dibandingkan dengan total resiko yang dihadapi perusahaan.

\section{2) Non Performing Loan (NPL) pada PT Bank Rakyat Indonesia (Persero), Tbk yang terdaftar di Bursa} Efek Indonesia Periode 2007-2014

Dari hasil penelitian, diketahui nilai minimum NPL PT Bank Rakyat Indonesia (Persero), Tbk periode 2007-2014 adalah sebesar 1,26\% terdapat di tahun 2014 pada semester II sedangkan nilai maksimum NPL adalah sebesar 5,45\% terdapat di tahun 2007 pada semester I. Nilai rata-rata NPL pada penelitian ini adalah sebesar $2,63 \%$.

Pada penelitian ini selama 8 semester, perusahaan memiliki nilai NPL di atas nilai rata-rata yang berarti nilai NPL yang semakin tinggi maka akan semakin besar jumlah kredit yang memiliki resiko sehingga kualitas kredit bermasalah semakin besar kemungkinan akan menyebabkan bank dalam kondisi bermasalah semakin besar dan selama 8 semester nilai NPL berada di bawah nilai rata-rata, artinya nilai NPL lebih kecil dibandingkan dengan total kredit yang diberikan oleh perusahaan sehingga semakin kecil pula tingkat resiko yang dihadapi oleh perusahaan.

\section{3) Market to Book Ratio (MBR) pada PT Bank Rakyat Indonesia (Persero), Tbk yang terdaftar di Bursa Efek Indonesia Periode 2007-2014}

Dari hasil penelitian, diketahui nilai minimum MBR PT Bank Rakyat Indonesia (Persero), Tbk periode 2007-2014 adalah sebesar 2,25 kali terdapat di tahun 2013 pada semester II sedangkan nilai maksimum MBR adalah sebesar 4,69 kali terdapat di tahun 2007 pada semester II. Nilai rata-rata MBR pada penelitian ini adalah sebesar 3,20 kali.

Pada penelitian ini selama 7 semester, perusahaan memiliki nilai MBR di atas nilai rata-rata yang berarti nilai MBR yang semakin tinggi maka akan semakin besar harga saham dibanding nilai buku per sahamnya dan kepercayaan masyarakat juga akan semakin tinggi sehingga nilai perusahaan juga akan meningkat dan selama 9 semester nilai MBR berada di bawah nilai rata-rata, artinya harga saham lebih kecil dibandingkan dengan nilai buku per sahamnya yang mengakibatkan nilai perusahaan juga akan menurun.

\section{c. Deskriptif Kuantitatif}

1) Analisis Regresi Linier Berganda

Berdasarkan hasil analisa dengan program SPSS, maka model regresi linear berganda yaitu sebagai berikut : $Y=2,660-0,011 X_{1}+0,269 X_{2}+\varepsilon$.

Berdasarkan hasil persamaan regresi di atas maka dapat disimpulkan bahwa struktur modal yang diproksikan dengan Capital Adequacy Ratio (CAR) berpengaruh negatif terhadap nilai perusahaan sedangkan Non Performing Loan (NPL) berpengaruh positif terhadap Nilai Perusahaan pada PT Bank Rakyat Indonesia, Tbk yang Terdaftar di Bursa Efek Indonesia.

\section{2) Analisa Korelasi dan Determinasi}

Berdasarkan hasil pengolahan data SPSS diperoleh nilai koefisien korelasi adalah sebesar 0,554. Dengan demikian dapat dikatakan bahwa korelasi atau hubungan antara CAR dan NPL terhadap MBR pada PT Bank Rakyat Indonesia (Persero), Tbk yang terdaftar di Bursa Efek Indonesia adalah cukup kuat.

Untuk nilai koefisien determinasi adalah sebesar 0,307 yang berarti bahwa MBR dapat dijelaskan oleh CAR dan NPL sebesar 30,7 \% pada PT Bank Rakyat Indonesia (Persero) periode 2007-2014 dan sisanya 69,3\% dijelaskan oleh variabel atau faktor lain yang tidak diteliti pada penelitian ini, seperti Return On Assets (ROA), Return On Equity (ROE) dan Long Term to Debt Ratio (LDR).

\section{3) Uji Hipotesis}

\section{a) Uji Simultan (Uji F)}

Uji statistik F pada dasarnya menunjukkan apakah semua variabel independen yang dimasukkan dalam model mempunyai pengaruh secara simultan terhadap semua variabel dependen. Tingkat signifikansi yang digunakan adalah sebesar $5 \%$, dengan level of confidence $95 \%(\alpha=0,05)$ dan degree of freedom $(\mathrm{n}-\mathrm{k})$ dan $(\mathrm{k}-1)$, dimana (n) adalah jumlah observasi dan (k) adalah jumlah variabel. 
Uji ini dilakukan dengan membandingkan signifikansi $\mathrm{F}_{\text {hitung }}$ dengan $\mathrm{F}_{\text {tabel }}$.

(1) Jika $\mathrm{F}_{\text {hitung }}>\mathrm{F}_{\text {tabel }}$ dan nilai probabilitas < 0,05 maka $\mathrm{H}_{0}$ ditolak, yang berarti bahwa Capital Adequacy Ratio (CAR) dan Non Performing Loan (NPL) secara silmultan berpengaruh signifikan terhadap Market to Book Ratio (MBR).

(2) Jika $\mathrm{F}_{\text {hitung }}<\mathrm{F}_{\text {tabel }}$ dan nilai probabilitas > 0,05 maka $\mathrm{H}_{0}$ diterima, yang berarti bahwa Capital Adequacy Ratio (CAR) dan Non Performing Loan (NPL) secara silmultan berpengaruh tidak signifikan terhadap Market to Book Ratio (MBR).

Dari hasil pengolahan data, dapat dilihat bahwa dengan tingkat kepercayaan 95\% , n-k-1=16-2-1=13, diperoleh angka $F_{\text {tabel }}$ sebesar 3,805 dan besar $F_{\text {hitung }}$ adalah 2,873. Karena $F_{\text {hitung }}<F_{\text {tabel }}$ atau 2,873<3,805 maka $\mathrm{H}_{0}$ diterima dan untuk tingkat signifikansi adalah $0,093>0,05$, maka keputusan yang diambil adalah Capital Adequacy Ratio (CAR) dan Non Performing Loan (NPL) secara simultan berpengaruh tidak signifikan terhadap Market to Book Ratio (MBR).

\section{b) Uji Parsial (Uji t)}

Uji t digunakan untuk menguji pengaruh variabel bebas terhadap variabel terikat secara parsial atau individual. Adapun hipotesis yang diuji adalah sebagai berikut :

(1) $\mathrm{H}_{0}$ ditolak jika $\mathrm{t}_{\text {hitung }}>\mathrm{t}_{\text {tabel }}$, artinya Capital Adequacy Ratio (CAR) dan Non Performing Loan (NPL) berpengaruh signifikan terhadap Market to Book Ratio (MBR).

(2) $\mathrm{H}_{0}$ diterima jika $\mathrm{t}_{\text {hitung }}<\mathrm{t}_{\text {tabel, }}$, artinya Capital Adequacy Ratio (CAR) dan Non Performing Loan (NPL) berpengaruh tidak signifikan terhadap Market to Book Ratio (MBR).

Hipotesis digunakan untuk menguji signifikansi koefisien persamaan regresi dirumuskan sebagai berikut

(1) Jika $t_{\text {hitung }}>t_{\text {tabel }}$ atau probabilitas signifikan $<\alpha(5 \%)$, maka $\mathrm{H}_{0}$ ditolak.

(2) Jika $t_{\text {hitung }}<t_{\text {tabel }}$ atau probabilitas signifikan $>\alpha(5 \%)$, maka $\mathrm{H}_{0}$ diterima.

Dari hasil uji t diperoleh kesimpulan sebagai berikut:

(1) Untuk variabel Capital Adequacy Ratio (CAR) dengan tingkat kepercayaan 95\%, n-k-1=16-2-1=13 dan $\alpha$ $(5 \% / 2=0,025)$, dari tabel $t$ diperoleh angka $t_{\text {tabel }}$ sebesar 2,119 dan besar $t_{\text {hitung }}$ adalah $-0,126$. Karena $t_{\text {hitung }}<$ $\mathrm{t}_{\text {tabel }}$ atau $-0,126<2,119$ maka $\mathrm{H}_{0}$ diterima dan untuk tingkat signifikansi adalah 0,901 > 0,05, maka keputusan yang diambil adalah Capital Adequacy Ratio (CAR) secara parsial berpengaruh negatif tidak signifikan terhadap Market to Book Ratio (MBR) pada PT Bank Rakyat Indonesia (Persero), Tbk yang terdaftar di Bursa Efek Indonesia.

(2) Untuk variabel Non Performing Loan (NPL) dengan tingkat kepercayaan 95\%, n-k-1=16-2-1=13 dan $\alpha$ $(5 \% / 2=0,025)$, dari tabel $t$ diperoleh angka $t_{\text {tabel }}$ sebesar 2,119 dan besar $t_{\text {hitung }}$ adalah 2,222. Karena $t_{\text {hitung }}>$ $\mathrm{t}_{\text {tabel }}$ atau 2,222 > 2,119 maka $\mathrm{H}_{0}$ ditolak dan untuk tingkat signifikansi adalah $0,045<0,05$, maka keputusan yang diambil adalah Non Performing Loan (NPL) secara parsial berpengaruh signifikan terhadap Market to Book Ratio (MBR) pada PT Bank Rakyat Indonesia (Persero), Tbk yang terdaftar di Bursa Efek Indonesia.

\section{Evaluasi}

a. Struktur Modal Pada PT Bank Rakyat Indonesia (Persero), Tbk yang terdaftar di Bursa Efek Indonesia

Hasil penelitian menunjukkan bahwa kondisi struktur modal yang diproksikan dengan Capital Adequacy Ratio (CAR) pada PT Bank Rakyat Indonesia (Persero), Tbk yang terdaftar di Bursa Efek Indonesia tahun 20072014 berfluktuasi. Hal ini dapat dilihat pada Capital Adequacy Ratio (CAR) pada PT Bank Rakyat Indonesia (Persero), Tbk tahun 2014 memiliki tingkat Capital Adequacy Ratio (CAR) yang tinggi yaitu 18,31\%. Sedangkan tingkat Capital Adequacy Ratio (CAR) terendah pada PT Bank Rakyat Indonesia (Persero), Tbk yaitu sebesar 13,18\% pada tahun 2008.

\section{b. Non Performing Loan (NPL) pada PT Bank Rakyat Indonesia (Persero), Tbk yang terdaftar di Bursa} Efek Indonesia

Hasil penelitian menunjukkan bahwa kondisi Non Performing Loan (NPL) pada PT Bank Rakyat Indonesia (Persero), Tbk yang terdaftar di Bursa Efek Indonesia tahun 2007-2014 berfluktuasi. Tingkat Non Performing Loan (NPL) yang tertinggi pada tahun 2007 yaitu sebesar 5,45\%. Sedangkan tingkat Non Performing Loan (NPL) terendah pada PT Bank Rakyat Indonesia (Persero), Tbk yaitu sebesar 1,26\% pada tahun 2014.

c. Nilai Perusahaan pada PT Bank Rakyat Indonesia (Persero), Tbk yang terdaftar di Bursa Efek Indonesia 
Hasil penelitian menunjukkan bahwa rata-rata Market to Book Ratio (MBR) pada PT Bank Rakyat Indonesia (Persero), Tbk yang terdaftar di Bursa Efek Indonesia adalah sebesar 3,20 kali. Hal ini menunjukkan bahwa PT Bank Rakyat Indonesia (Persero), Tbk yang terdaftar di Bursa Efek Indonesia memberi sinyal positif dan pandangan yang baik bagi para investor. Dimana kondisi ini menunjukkan bahwa rata-rata harga pasar saham PT Bank Rakyat Indonesia (Persero), Tbk adalah sebesar 3,20 kali dibanding nilai bukunya.

\section{d. Pengaruh Struktur Modal dan Non Performing Loan (NPL) terhadap Nilai Perusahaan pada PT Bank Rakyat Indonesia (Persero), Tbk yang terdaftar di Bursa Efek Indonesia}

Hasil penelitian menunjukkan bahwa Capital Adequacy Ratio (CAR) memiliki pengaruh negatif terhadap Market to Book Ratio (MBR) dan Non Performing Loan (NPL) memiliki pengaruh positif terhadap Market to Book Ratio (MBR). Hal ini dapat dilihat dari persamaan regresi yaitu $\mathrm{Y}=2,660-0,011 \mathrm{X}_{1}+0,269 \mathrm{X}_{2}+\varepsilon$.

Untuk variabel Capital Adequacy Ratio (CAR) adalah -0,011 yang berarti bahwa setiap peningkatan Capital Adequacy Ratio (CAR) sebesar 1 satuan maka akan menyebabkan penurunan nilai Market to Book Ratio (MBR) sebesar 0,011 satuan. Hasil penelitian ini sudah sejalan dengan teori yang dikemukakan oleh Darmawi (2011:18), yang menyatakan apabila ketentuan rasio kecukupan modal tidak terpenuhi, akan mengurangi ekspansi kredit dan mempengaruhi tingkat kesehatan bank yang akan mengurangi kepercayaan masyarakat.

Sementara untuk variabel Non Performing Loan (NPL) adalah 0,269 yang berarti bahwa setiap peningkatan Non Performing Loan (NPL) sebesar 1 satuan maka akan menyebakan peningkatan nilai Market to Book Ratio (MBR) sebesar 0,269 satuan. Hasil penelitian ini tidak sejalan dengan teori yang dikemukakan Taswan (2010:166), semakin tinggi nilai Non Performing Loan (NPL) maka semakin buruk kualitas kreditnya yang mengakibatkan nilai perusahaan akan menurun.

\section{KESIMPULAN DAN SARAN}

\section{Kesimpulan}

a. Rata-rata CAR yaitu sebesar $15,39 \%$. Untuk NPL memiliki nilai rata-rata yaitu sebesar 2,54\%. Sedangkan rata-rata MBR pada PT Bank Rakyat Indonesia (Persero), Tbk yang terdaftar di Bursa Efek Indonesia adalah sebesar 3,20 kali.

b. Dari hasil pengujian regresi linear berganda diketahui bahwa CAR memiliki pengaruh negatif terhadap MBR dan variabel NPL memiliki pengaruh positif terhadap MBR. Hal ini dapat dilihat dari persamaan regresi yaitu $\mathrm{Y}=2,660-0,011 \mathrm{X}_{1}+0,269 \mathrm{X}_{2}+\varepsilon$.

c. Dari uji koefisien korelasi diperoleh hasil bahwa korelasi atau hubungan variabel CAR dan NPL dengan MBR adalah cukup kuat. Sementara untuk uji koefisien determinasi diperoleh hasil bahwa MBR dapat dijelaskan oleh CAR dan NPL yaitu sebesar 30,7\%, sisanya sebesar 69,3\% dijelaskan oleh variabel lain yang tidak diteliti dalam penelitian ini seperti Return On Assets (ROA), Return On Equity (ROE) dan Long Term to Debt Ratio (LDR).

d. Dari hasil uji statistik $F$ diperoleh hasil $F_{\text {hitung }}<\mathrm{F}_{\text {tabel }}$ atau 2,873<3,805 maka $\mathrm{H}_{0}$ diterima dan untuk tingkat signifikansi adalah 0,093>0,05, maka keputusan yang diambil adalah CAR dan NPL secara simultan berpengaruh tidak signifikan terhadap MBR.

e. Dari hasil uji statistik $t$ diperoleh hasil bahwa secara parsial untuk variabel CAR : $t_{\text {hitung }}<t_{\text {tabel }}$ yaitu $-0,126$ $<2,119$ dan tingkat signifikan 0,901 > 0,05 yang berarti CAR secara parsial berpengaruh negatif tidak signifikan terhadap MBR. Sementara untuk variabel NPL diketahui bahwa $t_{\text {hitung }}>t_{\text {tabel }}$ yaitu 2,222 $>2,119$ dan tingkat signifikansi $0,045<0,05$ yang berarti bahwa NPL secara parsial berpengaruh positif signifikan terhadap MBR.

\section{Saran}

a. Bagi perusahaan, disarankan untuk tetap dapat mempertahankan tingkat kecukupan modal serta kualitas kreditnya. Apabila perusahaan menginginkan kepercayaan masyarakat yang tinggi dalam menginvestasikan dananya. Sehingga bank bisa dapat bertahan lebih lama lagi dan meningkatkan nilai peusahaan yang lebih baik lagi.

b. Bagi investor atau calon investor, disarankan untuk mengawasi kualitas kredit maupun struktur modal untuk mendorong nilai perusahaan. Karena besarnya harga saham yang diperoleh perusahaan mencerminkan tingkat pengembalian yang diterima oleh investor.

c. Sehubungan dengan keterbatasan pengetahuan penulis, diharapkan bagi peneliti selanjutnya sebaiknya perlu juga untuk memperluas bahasan mengenai rasio lainnya untuk mengukur nilai perusahaan dan rasio keuangan lainnya serta menggunakan objek penelitian yang lebih baik lagi. 


\section{E. DAFTAR PUSTAKA}

Ali, Mahsyud. 2006. Manajemen Resiko. Jakarta: PT Raja Grafindo Persada.

Brigham, Eugene F. dan Joel F. Houston. 2012. Dasar-dasar Manajemen Keuangan. Edisi Kesepuluh. Jilid Satu. Jakarta: Salemba Empat.

Darmawi, Herman. 2011. Manajemen Perbankan. Jakarta: Bumi Aksara

Dendawijaya, Lukman. 2005. Manajemen Perbankan. Edisi 2. Jakarta: Ghalia Indonesia.

Hariyani, Iswi. 2010. Restrukturisasi dan Penghapusan Kredit Macet. Jakarta: PT Elex Media Komputindo.

Horne, Van C. dan John M. Wachowicz. 2012. Prinsip-prinsip Manajemen Keuangan. Edisi 13. Buku 1. Jakarta: Salemba Empat.

Ismail. 2010. Manajemen Perbankan: Dari Teori Menuju Aplikasi. Edisi Satu. Jakarta: Kencana.

-----. 2010. Akuntansi Bank. Jakarta: Kencana.

Kasmir. 2010. Pengantar Manajemen Keuangan. Edisi 1. Jakarta : Kencana

Keown, Arthur J. et. al. 2004. Manajemen Keuangan: Prinsip-prinsip dan Aplikasi. Edisi 9. Jilid 1. Jakarta: PT Intermasa.

Munawir, S. 2004. Analisa Laporan Keuangan. Yogyakarta: Liberty.

Taswan. 2010. Manajemen Perbankan. Edisi 2. Yogyakarta: UPP STIM YKPN Yogyakarta.

Wild, John J. et. al. 2005. Financial Statement Analysis. Edisi 8. Buku 1. Jakarta: Salemba Empat. 